\title{
Development of a Fungicide-Based Management Strategy for Foliar Disease Caused by Phoma ligulicola in Tasmanian Pyrethrum Fields
}

Sarah J. Pethybridge and Frank S. Hay, Tasmanian Institute of Agricultural Research (TIAR), University of Tasmania, Burnie, Tasmania, 7320, Australia; Calum R. Wilson, TIAR, New Town Research Laboratories, New Town, Tasmania, 7008, Australia; and Tim Groom, Botanical Resources Australia Pty. Ltd., Ulverstone, Tasmania, 7315, Australia

\begin{abstract}
Pethybridge, S. J., Hay, F. S., Wilson, C. R., and Groom, T. 2005. Development of a fungicidebased management strategy for foliar disease caused by Phoma ligulicola in Tasmanian pyrethrum fields. Plant Dis. 89:1114-1120.

The efficacy of a range of fungicides were assessed under in vitro conditions in four field trials over three seasons for the management of ray blight of pyrethrum, caused by the fungus Phoma ligulicola in Tasmania. Fungicides belonging to the demethylation inhibitor group, including prochloraz, tebuconazole, difenoconazole, and cyproconazole, produced the most significant reduction in mycelial growth in vitro compared with unamended controls. Significant reductions in germination of conidia resulted from low concentrations of azoxystrobin. In the field, azoxystrobin (as Amistar) at a rate of $300 \mathrm{~g}$ of product/ha significantly decreased disease intensity and increased pyrethrin yield $(\mathrm{kg} / \mathrm{ha})$ in all seasons. Applications of either azoxystrobin or difenoconazole (as Score) at a rate of $250 \mathrm{ml}$ of product/ha in early spring were the most effective, whereas no significant benefit was demonstrated from applications in autumn. Over all seasons, azoxystrobin applications resulted in double the weight of flowers produced compared with nontreated areas, whereas increases in pyrethrin content within the flowers were season and location specific. Application of azoxystrobin and chlorothalonil (as Bravo 720) at a rate of 1.4 liters of product/ha resulted in a 45 to $48 \%$ increase in flowers, reduced defoliation, and increased stem diameter. The weight of individual flowers and flower maturity was not significantly affected by fungicide application. These data provide the basis for cost-effective management of this disease.
\end{abstract}

Additional keywords: disease management, Tanacetum cinerariaefolium

Pyrethrum (Tanacetum cinerariaefolium L.) is a perennial plant belonging to the family Compositae. It is grown commercially in Tasmania, Australia for the production of insecticidal pyrethrins, used in a range of products. Pyrethrins have several advantages over synthetically produced insecticides (e.g., reduced risk of resistance development, low mammalian toxicity, and rapid environmental breakdown in sunlight; 8). Pyrethrum currently is worth approximately AU\$25 million per annum to the Australian economy. The commercial life span of a pyrethrum field in Tasmania is 4 to 5 years and the time between termination and replanting of the same field into pyrethrum is approximately 4 years. Fields are planted between July and September and it is approximately 18 months before the first harvest occurs.

The most severe foliar disease in Tasmanian pyrethrum fields in spring and

Corresponding author: S. J. Pethybridge

E-mail: sarah_jp@utas.edu.au

Accepted for publication 7 June 2005.

DOI: 10.1094/PD-89-1114

(C) 2005 The American Phytopathological Society summer is ray blight, caused by Phoma ligulicola Baker, Dimock \& Davis v. Arx. This disease first was described in 1995 on flowers and buds (20) and subsequently found to cause a severe dieback of emerging flowering stems and leaves in spring (17). In the absence of management, epidemics can result in complete loss of yield and early termination of the crop due to reduction in plant density, as occurred in some fields in 2000 (18). The severity of the epidemic in 2000 and annual epidemics which have occurred since has subsequently dictated the rapid development of control measures for this disease.

$P$. ligulicola also causes ray blight in chrysanthemum (Chrysanthemum morifolium Ramat). The management of this disease in chrysanthemum relies upon the integration of many preventative strategies: minimal overhead irrigation and liquid fertilizers to prevent inoculum spread (9), irrigation schedules which encourage rapid drying of foliage (22), roguing of disease plants and subsequent elimination by burning (9), use of resistant or later-flowering cultivars (1), and the use of material certified free of the pathogen $(2,22)$. Baker et al. (3) recommended that planting material be sourced from dry regions because the pathogen is likely to be present but often symptomless within material in regions characterized by frequent rainfall during the growing season. The pathogen is believed to have spread throughout the United States via infected cuttings (4). Additional control measures include soil sterilization to minimize inoculum contribution from pseudosclerotia $(4,5,9)$, deep burial of all residual plant material (3), a rotation of at least 3 years $(3,4)$, removal and burning of crop debris $(3,4,22)$, wider spacing and improved ventilation within the canopy (3), and fungicide application (9). Fungicides that have been demonstrated to be effective in ray blight management in chrysanthemum are zinc ethylenebis(dithiocarbamate) (as Zineb) $(1,4)$, $\mathrm{N}$-(trichloromethylthio)-4-cyclohexene-1,2dicarboximide (as Captan) (4), benomyl (as Benlate), chlorothalonil (as Bravo), mancozeb (as Dithane) (22), zinc ethylenebis-dithiocarbamate (as Parzate), and dichloronaphthoquinone (as Phygon) (3). A 7- to 10-day application schedule for the fungicides has been recommended $(3,4,22)$. No information exists on the efficacy of newly developed fungicides to this disease in chrysanthemum, because management increasingly is reliant upon the use of resistant cultivars.

In Tasmanian pyrethrum production, disease management challenges differ from those of chrysanthemum. For example, overhead irrigation which may encourage disease is used to supplement rainfall at certain times of the year. Pyrethrum is a perennial crop located in a relatively small geographic area; therefore, there potentially are many sources of inoculum. The contribution of pseudosclerotia to the epidemic is unknown; nevertheless, the cost of soil sterilization to reduce soil inoculum would be prohibitive. Furthermore, although $P$. ligulicola can be detected in pyrethrum seed, the contribution of seed infection to the epidemic in comparison to other sources is presently unknown (S. J. Pethybridge, unpublished data). This article presents new research on the efficacy and optimal timing of a range of commercially available fungicides for the management of severe foliar disease epidemics caused by $P$. ligulicola since 2000.

\section{MATERIALS AND METHODS}

In vitro efficacy of fungicides against P. ligulicola. Four concentrations of 12 
fungicides were tested in vitro for their inhibitory effect on the mycelial growth of three $P$. ligulicola isolates obtained from diseased pyrethrum flower buds in 1999 from each of the three main production districts (Sassafras/Wesley Vale: Universal Transverse Mercator [UTM] co-ordinates 55 G 457297 5440171; Forth/Kindred: 424853 5438396; and Wynyard: 380348 5466219). A representative culture of the $P$. ligulicola isolates used in this work has been deposited at the New South Wales Agriculture Herbarium, Australia (DAR 70020). Fungicides were dissolved in sterile water and sterilized in $70 \%$ ethanol. A dilution series was made in sterile water and appropriate aliquots added to molten $\left(65^{\circ} \mathrm{C}\right)$ potato dextrose agar (PDA) to achieve concentrations of $0,0.5,5,50$, and $500 \mu \mathrm{l}$ or $\mu \mathrm{g}$ a.i. $/ \mathrm{ml}$. The fungicides used in this trial were chlorothalonil, mancozeb, oxydixyl and propineb, benomyl, procymidone, cyproconazole, tebuconazole, difenoconazole, prochloraz, copper oxychloride, and iminoctadine tris albesilate (Table 1). Three replicates of each plate were inoculated with a 5-mm-diameter plug taken from the edge of an actively growing $P$. ligulicola colony on PDA. Plugs of each isolate were placed in the center of each plate and grown on PDA in the dark at $20^{\circ} \mathrm{C}$. Colony diameters were measured at 15 days after inoculation and compared with those of unamended plates by analysis of variance. The significance of any interactions between fungicides and isolate was also assessed (Genstat 5, version 3.2, Adept Scientific Inc., Bethesda, $\mathrm{MD})$.

The inhibitory effect of azoxystrobin to the same three $P$. ligulicola isolates used in the above studies was assessed using a spore germination assay $(12,16)$. Azoxystrobin was dissolved in $100 \%$ acetone and adjusted to concentrations of 1,10 , or $100 \mathrm{mg} / \mathrm{ml}$. Salicylhydroxamic acid (SHAM; Sigma-Aldrich Co., St. Louis, MO) was dissolved in acetone and methanol (1:1) at a concentration of $100 \mathrm{mg} / \mathrm{ml}$. Azoxystrobin was added to autoclaved 2\% water agar (WA) cooled to $55^{\circ} \mathrm{C}$ at concentrations of $0.04,0.16$, and $0.625 \mu \mathrm{g} / \mathrm{ml}$. All concentrations also were amended with SHAM at $100 \mu \mathrm{g} / \mathrm{ml}$ to inhibit the alternative oxidase respiratory pathway $(12,16)$. The concentrations of both acetone and ethanol in all WA media were $1 \mathrm{ml} / \mathrm{liter}$. In addition to the concentrations tested, control plates consisting of either WA only or WA amended with SHAM also were included.

Sporulation of each isolate was induced by transferring a $5-\mathrm{mm}$ mycelial plug onto V8 juice agar ( $800 \mathrm{ml}$ of V8 juice, $200 \mathrm{ml}$ of distilled water, and $16 \mathrm{~g}$ of agar). These plates were incubated under cool white fluorescent light with a 14-h photoperiod at $20^{\circ} \mathrm{C}$ for 8 days. Conidial suspensions were prepared for each isolate by removing $5-\mathrm{cm}^{2}$ blocks of agar with pycnidia, mixing in $5 \mathrm{ml}$ of sterile distilled water, and adjusting the concentration of conidia to $5 \times 10^{4} / \mathrm{ml}$. Aliquots $(100 \mu \mathrm{l})$ of each isolate were spread on three replicate plates of each concentration and control plates and incubated at $20^{\circ} \mathrm{C}$ in the dark for $18 \mathrm{~h}$. The percentage of germinated conidia, defined as the presence of a germ tube at least the size of the conidium, was recorded for three replicates of 100 conidia within each plate which then were averaged. The effect of azoxystrobin concentration on germination of conidia (\%) compared with those of unamended plates was assessed by analysis of variance. The significance of any interactions between concentration and $P$. ligulicola isolate also was assessed (Genstat 5, version 3.2).

Efficacy and timing of fungicides for the control of foliar disease in the field. Trial design. Two trials were conducted over two seasons to examine the efficacy of a range of fungicides on foliar disease caused by $P$. ligulicola in Tasmanian pyrethrum fields. Trials were conducted at Kindred (55 G 434528 5434647) in 2000 and Sisters Creek (380146 5466162) in 2002. In 2000, the efficacies of the following fungicides were compared: tebuconazole (150.5 g a.i./ha), prochloraz (247.5 g a.i./ha), azoxystrobin (250 g a.i./ha), and chlorothalonil (1,440 g a.i./ha). Details of fungicides are listed in Table 1. Fungicides were applied three times, on 13 August, 15
September, and 4 October 2000. In 2002 at Sisters Creek, treatments were azoxystrobin (150 g a.i./ha), didecyldimethylammonium chloride (36 g a.i./ha), chlorothalonil (1,008 $\mathrm{g}$ a.i./ha), polysulfide sulfur (1,800 g a.i./ha), and copper oxychloride (750 g a.i./ha). Fungicides were applied on 11 September, 22 September, and 9 October 2002.

Trials conducted in 2001 also examined the timing of applications of fungicides and were located at Boat Harbour (397444 5457158) and Wynyard (394130 5458008). Spring applications in all trials were first applied to coincide with flowering stem heights of between 5 and $10 \mathrm{~cm}$. These locations are approximately $30 \mathrm{~km}$ apart; however, the Boat Harbour field represented an environment with an extended winter and higher rainfall. In both trials conducted in 2001, azoxystrobin (150 g a.i/ha) or difenoconazole (62.5 g a.i./ha) were applied separately, either in autumn or spring only, or at both times. Autumn applications were on 5 and 17 June and spring applications on 20 August and 27 October 2001. During autumn, plants were in a semidormant rosette form and no flowering stems were present.

All trials were conducted in commercial pyrethrum fields approaching either their first or second harvests. In 2000, the size of plots was $42 \mathrm{~m}^{2}$ ( 6 by $7 \mathrm{~m}$ ). Plots were separated by 3 -m-wide buffers to minimize spray drift. In trials conducted in 2001 and 2002 , plots were $35 \mathrm{~m}^{2}$ ( 7 by $5 \mathrm{~m}$ ) with 1 $\mathrm{m}$ buffers between plots. Each treatment, including nontreated control, was replicated five times in all trials. Treatments were arranged in a completely randomized design. In all trials, fungicides were applied with a custom-built sprayer (Crop Care Australasia, Pty. Ltd., York, Western Australia) with a 2-m boom fitted with Hardi 4110-12 flat fan nozzles spaced at $50-\mathrm{cm}$ intervals. The sprayer was pressurized $(200 \mathrm{kPa})$ with liquid petroleum gas (propane/butane), delivering 300 liters/ha.

Plant density and disease intensity estimation. Plant density (the number of plants per square meter) and disease intensity were assessed prior to the application of

Table 1. List of fungicides and active ingredients used in trials

\begin{tabular}{|c|c|c|}
\hline Product & Active ingredient & Supplier \\
\hline Amistar WG & Azoxystrobin at $500 \mathrm{~g} / \mathrm{kg}$ & Syngenta Australia \\
\hline Bravo 720 & Chlorothalonil at $720 \mathrm{~g} /$ liter & Syngenta Australia \\
\hline Dithane M45 & Mancozeb at $800 \mathrm{~g} / \mathrm{liter}$ & Dow Agrosciences Australia \\
\hline Fruvit & Propineb at $560 \mathrm{~g} / \mathrm{kg}$ and oxadixyl at $80 \mathrm{~g} / \mathrm{kg}$ & Bayer CropScience Australia \\
\hline Benlate & Benomyl at $500 \mathrm{~g} / \mathrm{kg}$ & DuPont Australia \\
\hline Sumisclex Broadacre & Procymidone at $500 \mathrm{~g} / \mathrm{liter}$ & Sumitomo Chemicals Australia \\
\hline Alto $100 \mathrm{SL}$ & Cyproconazole at $100 \mathrm{~g} / \mathrm{liter}$ & Syngenta Australia \\
\hline Sportak & Prochloraz at $450 \mathrm{~g} / \mathrm{liter}$ & Bayer CropScience Australia \\
\hline Chemspray & Copper oxychloride at $500 \mathrm{~g} / \mathrm{kg}$ & Garden King Products Pty. Ltd., Australia \\
\hline Bellkute & Iminoctadine tris(albesilate) at $400 \mathrm{~g} / \mathrm{kg}$ & Sumitomo Chemicals Australia \\
\hline Sporekill & Didecyldimethyl-ammonium chloride at $120 \mathrm{~g} / \mathrm{liter}$ & Lefroy Valley Australia \\
\hline Penncozeb DF & Mancozeb at $750 \mathrm{~g} / \mathrm{kg}$ & Atofina Australia \\
\hline Score & Difenoconazole at $250 \mathrm{~g} /$ liter & Syngenta Australia \\
\hline Folicur $430 \mathrm{SC}$ & Tebuconazole at $430 \mathrm{~g} /$ liter & Bayer Cropscience Australia \\
\hline Lime sulfur & Polysulfide sulfur at $200 \mathrm{~g} / \mathrm{liter}$ & Yates Australia \\
\hline
\end{tabular}


the first fungicides, followed by regular disease intensity assessments until harvest. The average plant density was calculated from the number of plants in three $1-\mathrm{m}^{2}$ quadrats in each plot on individual trials on 6 August 2000, 24 May 2001, and 10 September 2002. Disease intensity was assessed prior to fungicide application and in early spring when flowering stems had not yet fully developed, by systematic selection of 50 leaves in a "W" transect pattern across each plot. An average disease severity for each plot was calculated. Disease severity was assessed by estimating the area of the leaf affected by necrosis and comparing this with disease area diagrams constructed from scanned images of individual, full-size illustrations of pyrethrum leaves in 1998 (19). Prior studies have demonstrated that, from early spring (August) to harvest (December), the majority of necrotic lesions on pyrethrum result from infection by $P$. ligulicola (18). Assessments and estimation skills of the one person assessing severity were tested and refined using the training program "Epimodel." This program randomly presents the assessor with a range of diseased leaves and compares estimated severity with actual severity so the assessor can refine his or her skills $(14,15)$. Assessments of disease severity prior to fungicide application were made on the same day as plant density estimations. Assessments of disease severity in this manner were made following fungicide applications on 12 September and 15 November 2000, 11 July and 30 August 2001, and 6 September 2001. When sufficient flowering stems were available in 2001 and 2002, disease severity was assessed using the flowering stem as the sampling unit. Thirty flowering stems were systematically selected along a "W" transect across each plot. These stems were cut at the base of the plant and transported to the laboratory at $4^{\circ} \mathrm{C}$. Disease intensity on each stem was assessed within $48 \mathrm{~h}$ of collection. For each flowering stem, defoliation severity and incidence of ray blight was measured. Defoliation severity was defined as the height to defoliation (i.e., the length of the stem from the base at which leaves were either completely necrotic or abscised as a percent of total stem length). The incidence of ray blight was defined as the number of diseased flowers divided by the total number of flowers. In addition to these measures, in the trial conducted in 2002, the effect of fungicides on the number of flowers (and therefore branches along the main flowering stem) and stem diameter ( $\mathrm{mm}$ ) measured by calipers at $5 \mathrm{~cm}$ above the base of the stem also were assessed. For all assessments, the average was calculated for each plot and used in an analysis of variance to determine the effect of each fungicide (Genstat 5, version 3.2).

Effect of fungicides on flower and pyrethrin yield. Flowers were hand harvested from four quadrats $\left(1 \mathrm{~m}^{2}\right)$ in each plot between 14 and 17 December in each year (approximately 10 days prior to commercial harvest of the entire field). The weight of fresh flowers was recorded after storage at $4^{\circ} \mathrm{C}$ for $24 \mathrm{~h}$. The dry weight of a subsample comprising $20 \%( \pm 2 \%)$ of the total fresh weight of flowers was recorded after drying at $70^{\circ} \mathrm{C}$ for $24 \mathrm{~h}$.

Pyrethrins were extracted from $20 \mathrm{~g}$ of pyrethrum flowers following drying at $55^{\circ} \mathrm{C}$. Samples were ground to a fine powder prior to extraction with hexane, sonicated for $20 \mathrm{~min}$ with shaking, and allowed to stand for $16 \mathrm{~h}$ prior to being passed through a $0.45-\mu \mathrm{m}$ filter. Samples were analyzed using normal phase highperformance liquid chromatography on a Shimadzu system (13). The column was a Waters Resolve Silica 8-by-100 mm (5 $\mu \mathrm{m})$ with a silica guard column. The mobile phase was a solution of heptane and $4 \%$ tetrahydrofuran at $4 \mathrm{ml} / \mathrm{min}$. Pyrethrins were detected by ultraviolet light at a wavelength of $223 \mathrm{~nm}$. Samples were compared against a validated reference standard of pyrethrins extracted from plant material.

The maturity of flowers was assessed on a further subsample (200 g) using the flower maturity index. Each flower within the sample was examined and placed into one of the eight pre-defined flower stages: (i) buds greater than $3 \mathrm{~mm}$ in diameter and buds with ray florets green and cone shaped; (ii) buds just opening with ray florets vertical and no disc florets open; (iii) ray florets horizontal and disc florets open in less than one-third of the radius; (iv) ray florets horizontal and disc florets open in between one-third and two-thirds of the radius; (v) ray florets horizontal and white, and at least two-thirds of disc florets open; (vi) ray florets intact, all ray florets open, and flower head surface turning necrotic; (vii) disc florets intact and turning necrotic and ray florets drying out and abscising; and (viii) disc and ray florets missing, flower and stem necrotic. The number of flowers within each flower stage category was counted and multiplied by a scaling factor to achieve a weighted mean average assessment of flower maturity. Within the flower sample assessed for maturity, the number of flowers (healthy and diseased due to infection by $P$. ligulicola) also was counted. From these numbers, the incidence of ray blight was calculated as (diseased flowers/healthy flowers) $\times$ 100. The effect of fungicides on dry weight of flowers $(\mathrm{g})$, pyrethrin content $(\%)$, pyrethrin yield $(\mathrm{kg} / \mathrm{ha})$, and the incidence of ray blight $(\%)$ was assessed by analysis of variance (Genstat 5, version 3.2).

\section{RESULTS}

In vitro efficacy of fungicides against P. ligulicola. The diameter of in vitro mycelial growth of $P$. ligulicola was reduced significantly $(P<0.001)$ by amendment with all of the fungicides tested; however, the concentration at which mycelial growth was reduced varied with fungicide (Table 2). Significant reductions in colony diame-

Table 2. Effect of a range of fungicides on in vitro mycelial growth $(\mathrm{mm})$ and spore germination $(\%)$ averaged over three Phoma ligulicola isolates $(P<$ $0.001)$

\begin{tabular}{|c|c|c|c|c|c|c|c|c|c|c|}
\hline \multirow[b]{2}{*}{ Fungicide } & \multicolumn{10}{|c|}{ Concentration $(\mu \mathrm{g} / \mathrm{ml})^{x}$} \\
\hline & $\mathbf{0}$ & 0.5 & 5 & 50 & 500 & LSD & SHAM only & 0.04 & 0.16 & 2.5 \\
\hline Copper oxychloride ${ }^{y}$ & $64.8 \mathrm{~b}$ & $68.8 \mathrm{a}$ & $68.8 \mathrm{a}$ & $72.1 \mathrm{a}$ & $24.2 \mathrm{c}$ & 4.7 & $\ldots$ & $\ldots$ & $\ldots$ & $\ldots$ \\
\hline Iminoctadine tris(albesilate) $)^{\mathrm{y}}$ & $64.5 \mathrm{a}$ & $62.1 \mathrm{a}$ & $5.4 \mathrm{~b}$ & $5.2 \mathrm{~b}$ & $5.3 \mathrm{~b}$ & 2.4 & $\ldots$ & $\ldots$ & $\ldots$ & $\ldots$ \\
\hline Benomyl & $41.8 \mathrm{a}$ & $42.1 \mathrm{a}$ & $8.6 \mathrm{~b}$ & $6.0 \mathrm{c}$ & $5.2 \mathrm{c}$ & 1.4 & $\ldots$ & $\ldots$ & $\ldots$ & $\ldots$ \\
\hline Chlorothalonil & $41.8 \mathrm{a}$ & $41.2 \mathrm{a}$ & $41.1 \mathrm{a}$ & $41.8 \mathrm{a}$ & $37.6 \mathrm{~b}$ & 0.9 & $\ldots$ & $\ldots$ & $\ldots$ & $\ldots$ \\
\hline Cyproconazole & $41.8 \mathrm{a}$ & $24.8 \mathrm{~b}$ & $6.3 \mathrm{c}$ & $5.0 \mathrm{~d}$ & $5.0 \mathrm{~d}$ & 0.8 & $\ldots$ & $\ldots$ & $\ldots$ & $\ldots$ \\
\hline Difenoconazole & $41.8 \mathrm{a}$ & $10.9 \mathrm{~b}$ & $6.7 \mathrm{c}$ & $5.6 \mathrm{~d}$ & $5.6 \mathrm{~d}$ & 1.0 & $\ldots$ & $\ldots$ & $\ldots$ & $\ldots$ \\
\hline Mancozeb & $41.8 \mathrm{a}$ & $39.0 \mathrm{~b}$ & $38.8 \mathrm{~b}$ & $35.2 \mathrm{c}$ & $26.8 \mathrm{~d}$ & 0.7 & $\ldots$ & $\ldots$ & $\ldots$ & $\ldots$ \\
\hline Prochloraz & $41.8 \mathrm{a}$ & $15.3 \mathrm{~b}$ & $9.8 \mathrm{c}$ & $6.1 \mathrm{~d}$ & $5.1 \mathrm{~d}$ & 2.1 & $\ldots$ & $\ldots$ & $\ldots$ & $\ldots$ \\
\hline Procymidone & $41.8 \mathrm{a}$ & $44.4 \mathrm{~b}$ & $6.7 \mathrm{~d}$ & $5.9 \mathrm{~d}$ & $8.6 \mathrm{c}$ & 1.4 & $\ldots$ & $\ldots$ & $\ldots$ & $\ldots$ \\
\hline Propineb/oxadixyl & $41.8 \mathrm{a}$ & $40.8 \mathrm{~b}$ & $39.8 \mathrm{c}$ & $32.6 \mathrm{~d}$ & $21.3 \mathrm{e}$ & 0.4 & $\ldots$ & $\ldots$ & $\ldots$ & $\ldots$ \\
\hline Tebuconazole & $41.8 \mathrm{a}$ & $20.9 \mathrm{~b}$ & $5.3 \mathrm{c}$ & $5.0 \mathrm{c}$ & $5.0 \mathrm{c}$ & 0.6 & $\ldots$ & $\ldots$ & $\ldots$ & $\ldots$ \\
\hline Azoxystrobin ${ }^{z}$ & $97.9 \mathrm{a}$ & $\ldots$ & $\ldots$ & $\ldots$ & $\ldots$ & 1.3 & $96.6 \mathrm{a}$ & $76.1 \mathrm{~b}$ & $48.6 \mathrm{c}$ & $0 \mathrm{~d}$ \\
\hline
\end{tabular}

${ }^{x}$ Concentration of $0=$ unamended; LSD = least significant difference; SHAM = salicylhydroxamic acid. Within rows, means followed by the same letter are not significantly different at $P=0.05$.

${ }^{y}$ Growth trials for copper oxychloride and iminoctadine tris(albesilate) were separate from other fungicide experiments, hence using a different colony diameter for control.

${ }^{\mathrm{z}}$ In vitro efficacy testing of azoxystrobin was conducted by a spore germination test (16). 
ter by amendment with copper oxychloride and chlorothalonil occurred only at the highest concentration (500 $\mu \mathrm{g}$ a.i./ml). Amendment with propineb/oxadixyl significantly reduced mycelial growth at all concentrations and each increase in concentration was associated with a significant reduction in colony diameter compared with the lower concentration. However, even at concentrations of $500 \mu \mathrm{g}$ a.i./ml, the diameter of colonies was only $50 \%$ less than those on unamended plates (Table 2). Amendment with benomyl and procymidone at concentrations of at least $5 \mu \mathrm{g}$ a.i./ml significantly reduced colony diameters by 80 to $86 \%$ compared with unamended plates. Amendment with difenoconazole, cyproconazole, tebuconazole, and prochloraz reduced colony diameter by approximately 87 to $89 \%$ at the highest concentration tested, and concentrations of at least $0.5 \mu \mathrm{g}$ a.i. $/ \mathrm{ml}$ significantly reduced colony diameters compared with unamended plates (Table 2). Concentrations of iminoctadine tris(albesilate) greater than 5 $\mu \mathrm{g}$ a.i./ml significantly reduced colony diameter (Table 2). No significant interactions between fungicide and isolate were identified $(P=0.651)$.

In a spore germination assay, all three isolates were highly sensitive to azoxystrobin (Table 2). Amendment of media with SHAM had no significant effect on the germination of conidia. Concentrations of azoxystrobin greater than $0.04 \mu \mathrm{g}$ a.i./ml significantly reduced germination compared with unamended plates. Furthermore, the germination of conidia was completely inhibited by a concentration of $2.5 \mu \mathrm{g}$ a.i./ml (Table 2). No significant interactions between concentration and isolate were demonstrated $(P=0.452)$.

Efficacy of fungicides for the control of foliar disease in the field. Efficacy of azoxystrobin, chlorothalonil, prochloraz, and tebuconazole in 2000. On 6 August, prior to the application of fungicides in late winter (13 August), there was no significant difference in disease severity on leaves $(P=0.629)$ or plant density $(P=$ $0.451)$ between treatments. After the second application of fungicides on 15 September, there was no significant difference between treatments in disease severity on leaves $(P=0.903)$. However, after the third fungicide application (4 October), defoliation severity and the incidence of ray blight in November were significantly less in plots receiving prochloraz, azoxystrobin, and chlorothalonil compared with nontreated plots (Table 3). Tebuconazole did not significantly decrease defoliation severity and the incidence of ray blight within the flowers in November and December or the dry weight of flowers per square meter compared with nontreated plots (Table 3). Applications of chlorothalonil reduced defoliation severity by $53 \%$ compared with nontreated plots in November and reduced the incidence of ray blight by $65 \%$ on 14 December (Table 3). Prochloraz also significantly reduced disease intensity at all times, ranging from 20 to $77 \%$ less ray blight on 15 November and 14 December, respectively (Table 3). Chlorothalonil and prochloraz did not increase the dry weight of flowers or pyrethrin yield (kg/ha). Applications of azoxystrobin significantly reduced defoliation severity in November and the incidence of ray blight in November and December by 85 , 55, and 90\%, respectively. Azoxystrobin treatment resulted in nearly double the dry weight of flowers, a $6.8 \%$ increase in pyrethrin content within the flowers, and a $51 \%$ increase in pyrethrin yield $(\mathrm{kg} / \mathrm{ha})$ compared with nontreated plots (Table 3 ). All fungicides significantly increased pyrethrin assay within the flowers compared with nontreated (Table 3). None of the fungicides tested had any significant effect on the maturity of flowers $(P=0.791)$.

Efficacy of azoxystrobin, didecyldimethyl-ammonium chloride, chlorothalonil, polysulfide sulfur, mancozeb, and copper oxychloride in 2002. No significant differences were identified in plant density $(P=0.457)$ and disease severity on 10 September $(P=0.526)$ prior to fungicide applications on 11 and 22 September and 9 October 2002. Significant differences were identified on 6 November in disease intensity and plant physiological parameters following applications of azoxystrobin, mancozeb, polysulfide sulfur, and chlorothalonil (Table 4). Defoliation severity also was decreased significantly by these fungicides, with $74 \%$ less defoliation in plots receiving azoxystrobin compared with nontreated plots on 6 November. The height of flowering stems in plots treated with azoxystrobin, chlorothalonil, polysulfide sulfur, and mancozeb were 49, 39, 18, and $26 \%$ higher, respectively, than those in nontreated plots on 6 November. On 16 December, flowering stem heights in azoxystrobin and chlorothalonil treatments were 8 and $11 \%$ greater, respectively, than nontreated. On 16 December, defoliation severity was 65 and $61 \%$ lower in azoxystrobin and chlorothalonil treatments, respectively, compared with nontreated (Table 4). Mancozeb also significantly reduced defoliation severity compared with nontreated plots, but was less effective than azoxystrobin or chlorothalonil (Table 4). Azoxystrobin or chlorothalonil also reduced the incidence of ray blight to less than $1 \%$, and at least doubled the number of flowers on each flowering stem and the diameter of each stem compared with nontreated plants (Table 4).

Fungicide application also significantly increased the dry weight of flowers $(P<$ $0.001)$, reduced the incidence of ray blight, but had no effect $(P=0.658)$ on the average dry weight of one flower. The dry weight of flowers harvested from plots treated with azoxystrobin, chlorothalonil, and those receiving the commercially recommended protocol was 48,45 , and $56 \%$ higher, respectively, than those which did not receive any fungicides (Table 4). The dry weight of flowers in plots receiving mancozeb, didecyldimethyl-ammonium chloride, and polysulfide sulfur also were significantly higher than plots receiving copper oxychloride or nontreated plots but, on average, these yielded approximately half that of the more effective fungicides. Azoxystrobin, chlorothalonil, and the commercially recommended protocol were the most effective at increasing pyrethrin yield (kg/ha), with yields 36,41 , and $45 \%$ higher, respectively, than that obtained from nontreated plants (Table 4). Fungicides had no significant effect on flower maturity $(P=0.381)$ or pyrethrin content within the flowers $(P=0.181)$.

Timing of azoxystrobin and difenconazole for the control of foliar disease

Table 3. Effect of tebuconazole, prochloraz, chlorothalonil, and azoxystrobin in early spring on defoliation severity and incidence of ray blight (\%) on 15 November 2000, and incidence of ray blight $(\%)$, the dry weight of flowers $\left(\right.$ per $\mathrm{m}^{2}$ ), and relative pyrethrin content within the flowers and yield (compared with nontreated plots) on 14 December 2000 at Kindred, Tasmania ${ }^{z}$

\begin{tabular}{|c|c|c|c|c|c|c|}
\hline \multirow[b]{2}{*}{ Fungicide } & \multicolumn{2}{|c|}{15 November } & \multicolumn{4}{|c|}{14 December } \\
\hline & $\begin{array}{c}\text { Defoliation } \\
\text { severity (\%) }\end{array}$ & $\begin{array}{c}\text { Incidence of } \\
\text { ray blight }(\%)\end{array}$ & $\begin{array}{c}\text { Incidence of ray } \\
\text { blight }(\%)\end{array}$ & $\begin{array}{l}\text { Increase in dry weight } \\
\text { of flowers } / \mathbf{m}^{2}(\%)\end{array}$ & $\begin{array}{l}\text { Increase in pyrethrin } \\
\text { content in flowers }(\%)\end{array}$ & $\begin{array}{c}\text { Increase in pyrethrin } \\
\text { yield in } \mathrm{kg} / \mathrm{ha}(\%)\end{array}$ \\
\hline Azoxystrobin & $10 \mathrm{c}$ & $20 \mathrm{c}$ & $1.9 \mathrm{~b}$ & 49 & 6.8 & 51 \\
\hline Chlorothalonil & $31.2 \mathrm{~b}$ & $39.2 \mathrm{ab}$ & $6.6 \mathrm{~b}$ & ns & 7.8 & ns \\
\hline Prochloraz & $30 \mathrm{~b}$ & $35.6 \mathrm{~b}$ & $4.5 \mathrm{~b}$ & ns & 6.9 & ns \\
\hline Tebuconazole & $59.2 \mathrm{ab}$ & $42 \mathrm{ab}$ & $15 \mathrm{a}$ & $\mathrm{ns}$ & 5.6 & ns \\
\hline Nontreated & $65.1 \mathrm{a}$ & $44.4 \mathrm{a}$ & $18.8 \mathrm{a}$ & & & \\
\hline $\operatorname{LSD}(P)$ & $10.1(0.001)$ & $7.2(0.001)$ & $7.9(0.001)$ & $48(0.037)$ & $0.07(0.001)$ & $6.1(0.001)$ \\
\hline
\end{tabular}

${ }^{\mathrm{z}}$ Within columns, means followed by the same letter are not significantly different at $P=0.05$; ns $=$ not significant at $P=0.05$; LSD $=$ least significant difference. 
in the field. Fungicides were applied individually either in autumn (5 and 17 June), spring (20 August and 27 October), or both seasons. No significant differences were identified in plant density on 24 May at Boat Harbour $(P=0.228)$ or Wynyard $(P=$ $0.274)$, disease severity on leaves on 24 May at Boat Harbour $(P=0.221)$ or Wynyard $(P=0.74)$, or disease severity on leaves on 11 July at Boat Harbour $(P=$ $0.127)$ or Wynyard $(P=0.056)$. However, at both sites, disease severity was significantly higher $(P<0.001)$ in nontreated areas than in all other treatments on 30 August (Table 5). On 28 November, significant reductions in defoliation severity of 58 to 73,40 to 41,55 to 73 , and 41 to $43 \%$ were associated with application of azoxystrobin in spring, difenoconazole in spring, azoxystrobin in autumn and spring, and difenoconazole in autumn and spring, respectively, over the two sites. Applications of azoxystrobin in autumn did not significantly reduce the incidence of ray blight on 28 November at Wynyard (Table 5). On 28 November, fungicide application in spring resulted in significant increases in stem height at Boat Harbour but not Wynyard. At Boat Harbour, applications of azoxystrobin in spring and azoxystrobin in spring and autumn were the most effective treatments, increasing flowering stem height by 41 and $38 \%$, respectively (Table 5).

At both sites, fungicide treatments in spring only, or when combined with autumn applications, were associated with a significant increase in the total dry weight of flowers, pyrethrin assay within the flowers, and increased pyrethrin yield over nontreated plots (Table 6). At both sites, applications of azoxystrobin in spring only or autumn and spring and difenoconazole in spring only or autumn and spring significantly increased the dry weight of flowers by 52 to 86,45 to 66,45 to 46 , and 30 to $42 \%$, respectively, compared with nontreated. The incidence of ray blight at Boat Harbour ranged from $17.5 \%$ in plots receiving azoxystrobin in autumn only to less than $1 \%$ in plots receiving azoxystrobin in spring only. Compared with nontreated, pyrethrin content in the flowers was significantly higher in all fungicide treatments, with no significant differences between fungicide treatments. Pyrethrin yield was not significantly different between plots receiving either fungicide in autumn and nontreated plots. Moreover, the maximum increase in pyrethrin yield due to fungicide compared with nontreated was $74 \%$ at Boat Harbour from azox- ystrobin applications in spring (Table 6). At both sites, no significant differences were identified between any of the fungicide treatments and nontreated plants in flower maturity at Boat Harbour $(P=$ $0.173)$ or Wynyard $(P=0.739)$ or the average dry weight of individual flowers at Boat Harbour $(P=0.105)$ or Wynyard $(P=$ 0.307).

\section{DISCUSSION}

A range of fungicides within several resistance groups were screened for their efficacy against $P$. ligulicola under in vitro conditions and for the management of foliar disease caused by $P$. ligulicola in the field. Under in vitro conditions, the most effective fungicides at reducing mycelial growth were the demethylation inhibitors, such as tebuconazole, difenoconazole, cyproconazole, and prochloraz, which act by inhibiting the C-14 demethylation of 24-methylenedihydrolanosterol, a precursor of fungal sterol biosynthesis (6). These fungicides are used for the management of a wide range of foliar diseases caused by similar Ascomycete fungi. Azoxystrobin, a QoI inhibitor, was especially effective at reducing the germination of conidia at low concentrations in vitro and reducing disease intensity when applied under field

Table 4. Effect of azoxystrobin (Azo), chlorothalonil (Chloro), mancozeb (Manco), polysulfide sulfur (Poly), copper oxychloride (Cu oxy), and didecyldimethyl-ammonium chloride (Didecy) applications on defoliation severity (\%), the height of flowering stems (cm), and incidence of ray blight (\%) on 6 November, and flowering stem height $(\mathrm{cm})$, defoliation severity $(\%)$, incidence of ray blight $(\%)$, stem diameter $(\mathrm{mm})$, the number of flowers produced by each stem, dry weight of flowers (g), and pyrethrin yield (kg/ha) on 16 December 2002 at Sisters Creek, Tasmania ${ }^{\mathrm{y}}$

\begin{tabular}{|c|c|c|c|c|c|c|c|c|}
\hline \multirow[b]{2}{*}{ Measures } & \multicolumn{6}{|c|}{ Fungicides } & \multirow[b]{2}{*}{ Nontreated } & \multirow[b]{2}{*}{ LSD } \\
\hline & Azo & Chloro & Cu oxy & Poly & Manco & Didecy & & \\
\hline Stem height, 6 November & $66.5 \mathrm{a}$ & $62.3 \mathrm{a}$ & $44.4 \mathrm{~d}$ & $52.6 \mathrm{bc}$ & $56.1 \mathrm{~b}$ & $48 \mathrm{~cd}$ & $44.6 \mathrm{~d}$ & 48.2 \\
\hline Stem height, 16 December & $75.3 \mathrm{a}$ & $72 \mathrm{a}$ & NA & NA & $57.5 \mathrm{~b}$ & NA & $47.9 \mathrm{c}$ & 62.7 \\
\hline Defoliation, 6 November & $16.7 \mathrm{e}$ & $23.7 \mathrm{~d}$ & $66.5 \mathrm{a}$ & $49.3 \mathrm{~b}$ & $41.7 \mathrm{c}$ & $64.2 \mathrm{a}$ & $63.9 \mathrm{a}$ & 6.8 \\
\hline Defoliation, 16 December & $26.4 \mathrm{c}$ & $29.2 \mathrm{c}$ & NA & NA & $56.9 \mathrm{~b}$ & NA & $73.5 \mathrm{a}$ & 10.6 \\
\hline Ray blight, 6 November & $0.2 \mathrm{c}$ & $3.4 \mathrm{c}$ & NA & NA & $42.2 \mathrm{~b}$ & NA & $60 \mathrm{a}$ & 10.2 \\
\hline Ray blight, 16 December & $0.1 \mathrm{c}$ & $3.4 \mathrm{c}$ & NA & NA & $42.2 \mathrm{~b}$ & NA & $51.1 \mathrm{a}$ & 6.2 \\
\hline Stem diameter, 16 December & $4.1 \mathrm{a}$ & $3.8 \mathrm{a}$ & NA & NA & $3.2 \mathrm{~b}$ & NA & $2.8 \mathrm{c}$ & 0.34 \\
\hline Flowers/stem, 16 December & $6.3 \mathrm{a}$ & $5.6 \mathrm{a}$ & NA & NA & $3.7 \mathrm{~b}$ & NA & $3.2 \mathrm{~b}$ & 0.97 \\
\hline Increase in dry weight of flowers ${ }^{z}$ & $49 \mathrm{a}$ & $45 \mathrm{a}$ & $0 \mathrm{c}$ & $23 \mathrm{~b}$ & $13 \mathrm{~b}$ & $21 \mathrm{~b}$ & $0 \mathrm{c}$ & 13 \\
\hline Increase in pyrethrin yield ${ }^{\mathrm{z}}$ & $36 \mathrm{a}$ & $41 \mathrm{a}$ & $0 \mathrm{~b}$ & $10 \mathrm{~b}$ & $11 \mathrm{~b}$ & $3 b$ & $0 \mathrm{~b}$ & 9.2 \\
\hline
\end{tabular}

${ }^{y}$ LSD $=$ least significant difference $(P<0.001)$. Within columns, means followed by the same letter are not significantly different at $P=0.05 ; \mathrm{NA}=$ data not available because comparisons between these treatments and nontreated were not made.

${ }^{\mathrm{z}}$ Increase (\%) over nontreated.

Table 5. Effect of azoxystrobin and difenoconazole applications in spring or autumn on disease severity on leaves on 30 August, and flowering stem height, defoliation severity, and incidence of ray blight on 28 November 2001 at Boat Harbour (BH) and Wynyard (Wyn), Tasmania ${ }^{y}$

\begin{tabular}{|c|c|c|c|c|c|c|c|c|}
\hline \multirow[b]{2}{*}{ Fungicide (season) ${ }^{\mathrm{z}}$} & \multicolumn{2}{|c|}{$\begin{array}{c}\text { Disease severity on leaves } \\
(\%), 30 \text { Aug } \\
\end{array}$} & \multicolumn{2}{|c|}{$\begin{array}{c}\text { Stem height }(\mathrm{cm}), \\
28 \text { Nov } \\
\end{array}$} & \multicolumn{2}{|c|}{$\begin{array}{c}\text { Defoliation severity }(\%) \text {, } \\
28 \text { Nov }\end{array}$} & \multicolumn{2}{|c|}{$\begin{array}{c}\text { Ray blight (\%), } \\
28 \text { Nov }\end{array}$} \\
\hline & BH & Wyn & BH & Wyn & BH & Wyn & BH & Wyn \\
\hline Azoxystrobin (spring) & $13.1 \mathrm{~b}$ & $5 \mathrm{~b}$ & $57.2 \mathrm{a}$ & 54.2 & $28.3 \mathrm{~b}$ & $25.7 \mathrm{c}$ & $2.4 \mathrm{c}$ & $1.2 \mathrm{c}$ \\
\hline Azoxystrobin (autumn) & $8.6 \mathrm{~b}$ & $4.6 \mathrm{~b}$ & $50.7 \mathrm{~cd}$ & 48.1 & $59.1 \mathrm{a}$ & $89.6 \mathrm{a}$ & $14 \mathrm{ab}$ & $15.6 \mathrm{a}$ \\
\hline Difenoconazole (spring) & $9.4 \mathrm{~b}$ & $7.3 \mathrm{~b}$ & $49.7 \mathrm{~cd}$ & 53.1 & $40.1 \mathrm{~b}$ & $55.6 \mathrm{~b}$ & $4.4 \mathrm{c}$ & $8.2 \mathrm{~b}$ \\
\hline Difenoconazole (autumn) & $10.6 \mathrm{~b}$ & $7.4 \mathrm{~b}$ & $46.4 \mathrm{~d}$ & 47.5 & $58.7 \mathrm{a}$ & $83.4 \mathrm{a}$ & $12 \mathrm{~b}$ & $14.2 \mathrm{a}$ \\
\hline Azoxystrobin (autumn and spring) & $8.2 \mathrm{~b}$ & $6.2 \mathrm{~b}$ & $56.1 \mathrm{ab}$ & 51.9 & $29.8 \mathrm{~b}$ & $24.8 \mathrm{c}$ & $1.8 \mathrm{c}$ & $1.6 \mathrm{c}$ \\
\hline Difenoconazole (autumn and spring) & $11.4 \mathrm{~b}$ & $7.2 \mathrm{~b}$ & $52.2 \mathrm{bc}$ & 49.6 & $38.3 \mathrm{~b}$ & $55.7 \mathrm{~b}$ & $4.6 \mathrm{c}$ & $6.4 \mathrm{~b}$ \\
\hline Nontreated & $22 \mathrm{a}$ & $15.2 \mathrm{a}$ & $40.6 \mathrm{e}$ & 49.5 & $66.8 \mathrm{a}$ & $93.1 \mathrm{a}$ & $15 \mathrm{a}$ & $16.6 \mathrm{a}$ \\
\hline $\operatorname{LSD}(P)$ & $\begin{array}{l}5.9 \\
(0.001)\end{array}$ & $\begin{array}{l}5.6 \\
(0.001)\end{array}$ & $\begin{array}{l}4.9 \\
(0.001)\end{array}$ & $\begin{array}{l}0.406 \\
(\mathrm{~ns})\end{array}$ & $\begin{array}{l}14 \\
(<0.001)\end{array}$ & $\begin{array}{l}17.3 \\
(<0.001)\end{array}$ & $\begin{array}{c}2.4 \\
(<0.001)\end{array}$ & $\begin{array}{c}1.9 \\
(<0.001)\end{array}$ \\
\hline
\end{tabular}

y Within columns, means followed by the same letter are not significantly different at $P=0.05$.

${ }^{\mathrm{z}} \mathrm{LSD}=$ least significant difference; $\mathrm{ns}=$ not significant. 
conditions in spring. Mancozeb and chlorothalonil also were effective at reducing colony growth in vitro. Both these fungicides have been used effectively for the management of gummy stem blight epidemics caused by Didymella bryoniae $(10,11,21)$, a pathogen closely related to $P$. ligulicola.

Fungicides were chosen in consultation with the Tasmanian pyrethrum industry and decisions were based upon availability, price, and ease of adoption within the pyrethrum season. For example, procymidone was not tested in the field because it is already used throughout autumn for the management of Sclerotinia minor and more frequent use may lead to the development of resistance. Benomyl was not included in field trials because it has been withdrawn from the market and because similar carbendazim products are used for the control of flower disease in pyrethrum caused by $S$. sclerotiorum throughout November and December. In each trial and over three seasons, azoxystrobin consistently decreased disease intensity and increased pyrethrin yield $(\mathrm{kg} / \mathrm{ha})$ by between 49 and $74 \%$ over nontreated areas. Difenoconazole was included in trials conducted in 2001, because anecdotal evidence in the field had suggested its effectiveness in disease management.

The most efficient time for fungicide application was demonstrated in two fields in 2001 to be in spring, coinciding with emergence of young flowering stems. No additional benefits were demonstrated from additional fungicide applications in autumn aimed at reducing initial inoculum for foliar disease on leaves over winter. Subsequent work has demonstrated that disease of pyrethrum over the winter period is due mostly to fungi other than $P$. ligulicola $(17,19)$. The absence of an additional response to application of fungicides in the autumn fits with the need to reduce the rate of disease increase in a polycyclic disease for effective disease management and reduced yield loss (7).

Pyrethrin yield can be increased by two components: the number of flowers harvested and pyrethrin content within the flowers. Application of azoxystrobin in 2000 and 2001 and difenoconazole in 2001 were associated with increased pyrethrin content within the flowers. The magnitude of increase varied with location and season. Significant increases in the number of flowers harvested in each trial were demonstrated consistently in each season from application of azoxystrobin. However, from the trial conducted in 2002, flowers from plants treated with azoxystrobin were not larger or more mature than those from nontreated plants. The 2002 trial also demonstrated that the greater number of flowers per unit area from the azoxystrobin treatment arose from an increased number of flowers produced per stem. Stems also were thicker and taller in the azoxystrobin treatment compared with those of the nontreated plants. No relationship was demonstrated between fungicide application and either plant density or the number of stems produced by each plant, suggesting simply that the stems that did emerge were better able to produce flowers and pyrethrin because of significantly less defoliation during the season and, hence, increased opportunity for light interception.

Commercial recommendations of fungicides to growers began in 2001 with combinations of azoxystrobin (as Amistar), followed by applications of chlorothalonil (as Bravo) and difenoconazole (as Score) during spring. These products currently are registered on a minor use permit issued by the Australian Pesticides and Veterinary Medicines Authority (PER7649). Initial applications are recommended to begin prior to the first development of disease symptoms in mid-August annually. No more than three applications of either fungicide are recommended; however, in practice, fields receive one application of azoxystrobin and up to two applications of chlorothalonil and difenoconazole. The highest rates of difenoconazole (Score at $500 \mathrm{ml} / \mathrm{ha}$ ) always are recommended and applied as a tank mixture with chlorothalonil to minimize the probability of development of resistance to group C fungicides. Comparison of commercially rec- ommended combinations of these fungicides around the outside of the trial area in 2002 suggested that the yield benefits were equal to those gained from azoxystrobin or chlorothalonil alone at this site and resulted in almost a doubling in pyrethrin yield. However, site factors already have been demonstrated to have a highly significant impact on disease intensity within spring (17); therefore, the beneficial response to the farmer from applying these fungicides may vary. Further work will examine the effectiveness of these recommendations on a broader scale, track the sensitivity of $P$. ligulicola isolates to these fungicides over time, and identify sitespecific edaphic factors which may influence disease intensity. Despite only one application of azoxystrobin annually, the probability of resistance to strobilurin products is still high, especially due to the perennial nature of pyrethrum production. Screening of alternative products in different resistance groups to the strobilurins and demethylation inhibitors is also ongoing to make the commercial recommendations more durable in the longer term.

\section{ACKNOWLEDGMENTS}

This project was funded by Botanical Resources Australia Pty. Ltd., Horticulture Australia Limited, and the Australian Research Council Linkage program. We thank H. Faber of Botanical Resources Australia for pyrethrin analyses and pyrethrum growers who allowed access to their crops for field trials.

\section{LITERATURE CITED}

1. Anonymous 1956. Ray blight of chrysanthemums. Agric. Gaz. 309-310.

2. Baker, K. F., and Davis, L. H. 1959. Ascochyta disease of chrysanthemum appears in California. Calif. State Florists Assoc. Mag. 8:A-B.

3. Baker, K. F., Dimock, A. W., and Davis, L. H. 1949. Life history and control of the Ascochyta ray blight of chrysanthemum. Phytopathology 39:789-805.

4. Baker, K. F., Dimock, A. W., and Davis, L. H. 1961. Cause and prevention of the rapid spread of the Ascochyta disease of chrysanthemum. Phytopathology 51:96-101.

5. Blakeman, J. P., and Hornby, D. 1966. The persistence of Colletotrichum coccoides and Mycosphaerella ligulicola in soil, with special reference to sclerotia and conidia. Trans. $\mathrm{Br}$. Mycol. Soc. 49:227-240.

6. Buchenauer H. 1987. Mechanisms of action of triazolyl fungicides and related compounds.

Table 6. Effect of azoxystrobin and difenoconazole applications in spring or autumn on dry weight of flowers (g), the incidence of ray blight (\%), increase in pyrethrin content within the flowers, and pyrethrin yield (kg/ha) over nontreated on 14 December 2001 at Boat Harbour (BH) and Wynyard (Wyn), Tasmania $^{\mathrm{z}}$

\begin{tabular}{|c|c|c|c|c|c|c|c|}
\hline \multirow[b]{2}{*}{ Fungicide (season) } & \multicolumn{2}{|c|}{$\begin{array}{c}\text { Increase in dry weight } \\
\text { of flowers }(\%)\end{array}$} & \multicolumn{2}{|c|}{$\begin{array}{c}\text { Incidence } \\
\text { of ray blight }(\%)\end{array}$} & \multirow{2}{*}{$\begin{array}{c}\begin{array}{c}\text { Increase } \\
\text { in pyrethrin } \\
\text { content }(\%)\end{array} \\
\text { BH }\end{array}$} & \multicolumn{2}{|c|}{$\begin{array}{c}\text { Increase } \\
\text { in pyrethrin yield }(\%)\end{array}$} \\
\hline & BH & Wyn & BH & Wyn & & BH & Wyn \\
\hline Azoxystrobin (spring) & 86 a & $52 \mathrm{a}$ & $0.9 \mathrm{c}$ & $2.9 \mathrm{~b}$ & $6.8 \mathrm{a}$ & $74 \mathrm{a}$ & $42 \mathrm{ab}$ \\
\hline Azoxystrobin (autumn) & $6 c$ & $22 \mathrm{~cd}$ & $17.5 \mathrm{a}$ & $7.9 \mathrm{a}$ & $9.2 \mathrm{a}$ & $1.8 \mathrm{c}$ & $10 \mathrm{~cd}$ \\
\hline Difenoconazole (spring) & $46 \mathrm{~b}$ & $45 \mathrm{ab}$ & $1.7 \mathrm{c}$ & $4.2 \mathrm{~b}$ & $8.6 \mathrm{a}$ & $40 \mathrm{~b}$ & $46 \mathrm{a}$ \\
\hline Difenoconazole (autumn) & $16 \mathrm{c}$ & $24 \mathrm{bc}$ & $7.2 \mathrm{bc}$ & $4.4 \mathrm{~b}$ & $4.6 \mathrm{a}$ & $6.3 \mathrm{c}$ & 19 bcd \\
\hline Azoxystrobin (autumn and spring) & $66 \mathrm{ab}$ & $45 \mathrm{ab}$ & $5.8 \mathrm{bc}$ & $2.3 \mathrm{~b}$ & $7.4 \mathrm{a}$ & $57 \mathrm{ab}$ & $40 \mathrm{ab}$ \\
\hline Difenoconazole (autumn and spring) & $42 \mathrm{~b}$ & $30 \mathrm{bc}$ & $5.2 \mathrm{bc}$ & $4.3 \mathrm{~b}$ & $9.7 \mathrm{a}$ & $37 \mathrm{~b}$ & $31 \mathrm{abc}$ \\
\hline Nontreated & $0 \mathrm{c}$ & $0 \mathrm{~d}$ & $8.7 \mathrm{~b}$ & $10.4 \mathrm{a}$ & $0 \mathrm{~b}$ & $0 \mathrm{c}$ & $0 \mathrm{~d}$ \\
\hline$P$ & $<0.001$ & $<0.001$ & $<0.001$ & $<0.001$ & 0.016 & $<0.001$ & 0.006 \\
\hline
\end{tabular}

${ }^{\mathrm{z}}$ Within columns, means followed by the same letter are not significantly different at $P=0.05$. 
Pages 205-232 in: Modern Selective Fungicides-Properties, Applications and Mechanisms of Action. H. Lyr, ed. John Wiley and Sons, New York.

7. Campbell, C. L., and Madden, L. V. 1990. Introduction to Plant Disease Epidemiology. John Wiley and Sons, New York.

8. Casida, J. E., and Quistad, G. B. 1995. Pyrethrum Flowers: Production, Chemistry, Toxicology and Uses. Oxford University Press, New York.

9. Fox, R. T. V. 1998. Chrysanthemum ray blight. Mycologist 12:135-136.

10. Keinath, A. P. 2000. Effect of protectant fungicide application schedules on gummy stem blight epidemics and marketable yield of watermelon. Plant Dis. 84:254-260.

11. Keinath, A. P. 2001. Effect of fungicide applications scheduled to control gummy stem blight on yield and quality of watermelon fruit. Plant Dis. 85:53-58.

12. Ma, Z., Felts, D., and Michailides, T. J. 2003.
Resistance to azoxystrobin in Alternaria isolates from pistachio in California. Pest. Biochem. Physiol. 77:66-74.

13. McEldowney, A., and Menary, R. A. 1998. Analysis of pyrethrins in pyrethrin extracts by high-performance liquid chromatography. J. Chromatogr. 447:239-243.

14. Nutter, F. W., Jr., Gleason, M. S., Jenco, J. H., and Christians, N. C. 1997. Assessing the accuracy, intra-rater repeatability, and inter-rater reliability of disease assessment systems. Phytopathology 91:806-812.

15. Nutter, F. W., Jr., and Schultz, P. M. 1995. Improving the accuracy and precision of disease assessments: selection of methods and use of computer-aided training programs. Can. J. Plant Pathol. 17:174-184.

16. Olaya, G., Zheng, D., and Köller, W. 1998. Differential responses of germinating Venturia inequalis conidia to kresoxim-methyl. Pestic. Sci. 54:230-236.

17. Pethybridge, S. J., and Hay, F. S. 2001. Influ- ence of Phoma ligulicola on yield and site factors on disease development in Tasmanian pyrethrum crops. Aust. Plant Pathol. 30:17-20.

18. Pethybridge, S. J., Hay, F. S., and Groom, T. 2003. Seasonal fluctuations associated with pyrethrum foliage in Tasmania. Aust. Plant Pathol. 32:223-230.

19. Pethybridge, S. J., Hay, F. S., and Wilson, C. R. 2004. Pathogenicity of fungi commonly isolated from foliar disease in Tasmanian pyrethrum crops. Aust. Plant Pathol. 33:441-444.

20. Pethybridge, S. J., and Wilson, C. R. 1998 Confirmation of ray blight disease of pyrethrum in Australia. Aust. Plant Pathol. 27:45-48.

21. Shew, B. B. 2003. Evaluation of foliar fungicides for the control of peanut diseases in North Carolina, 2003. Fungic. Nematicide Tests (online). Report No. 57:SMF068. DOI: 10.1094/FN57.

22. Strider, D. L. 1994. Chrysanthemum diseases: a grower's guide. Rev. Chapingo Ser. Hortic. 1:131-135. 